\title{
Eğitimsel Açıdan Uygur ve Kıbrıs Türk Masal Kahramanları Bağlamında İletilen Olumsuz Mesajlar*
}

\author{
Yrd. Doç. Dr. Mustafa Yeniasır \\ Yakın Doğu Üniversitesi Atatürk Ĕ̆itim Fakültesi \\ Türkçe Öğretmenliği Bölümü \\ mustafa.yeniasir@neu.edu.tr
}

\author{
Yrd. Doç. Dr. Burak Gökbulut \\ Yakın Doğu Üniversitesi Fen ve Edebiyat Fakültesi \\ Türk Dili ve Edebiyatı Bölümü \\ burak.gokbulut@neu.edu.tr
}

Öz

1571'deki fetihten sonra Kıbrıs'a yerleştirilen Türkler son yüzyılda çok büyük bir var olma mücadelesi vermişler, büyük baskı ve zulümlerin ardından 15 Kasım 1983'te Türkiye'nin desteğiyle KKTC'yi kurmuşlardır. Çalışmada yer alan diğer Türk soylu devlet ise yaklaşık 24 milyonluk Uygur nüfusunun bulunduğu Doğu Türkistan'dır. Doğu Türkistan çok önemli ekonomik kaynaklara sahip olan fakat bunları Çin'in baskıları ve politikaları nedeniyle gerektiği gibi kullanamayan bir ülkedir. Milletlerin edebî ürünlerine ve sözlü kültür ürünlerine bakıldığında yaşadıkları sosyal-siyasî olayların yansıması açık bir şekilde görülmektedir. Bu anlamda iki halkın sözlü ürünlerinin her yönüyle incelenmesi büyük önem arz etmektedir. Bu sözlü ürünlerden olan masal bir konuda öğüt ve ders verme, çocukları eğitme vb. işlevleri olan, formel unsurlar, motifler ve tasvirler içerebilen, anlaşılır, sade bir dili olan, zamanın ve mekânın kesin olarak belli olmadığı sözlü, anonim halk edebiyatı türü olarak tanımlanabilir. Masalların eğitimsel işlevi özellikle üzerinde durulması gereken bir husustur. Çünkü çocuğun eğitiminde kullanılacak masalların özenle seçilmesinin gerekliliği ortadadır. Çalışmamızda her iki Türk toplumunun masallarında yer alan olumsuz unsurlar masal kahramanlarından hareketle gösterilmeye ve incelenmeye çalışılmıştır. Eğitimsel anlamda bakıldığında Kıbrıs Türk halk masallarında çocuklar açısından olumsuz olduğu düşünülen birtakım unsurları şu şekilde sıralamak mümkündür: Öldürme, şiddet, kıskançlık, açgözlülük, yalan söylemek, ahlâksızlık, dilencilik, sözden dönmek vs. Ele alınan metinlerden hareketle Uygur Türk halk masallarında rastlanan olumsuz unsurlar ise şunlardır: Rüşvet, açgözlülük, yalan söyleme, hirsızlık, afyon kullanımı, beddua, öldürme vs. İncelenen metinlerde yer alan olumsuz unsurlardan ve masalların olay örgülerinden hareketle Uygur Türk halk masallarının eğitimsel açıdan Kıbrıs Türk halk masallarına göre daha zayıf olduğunu söylemek mümkündür.

Anahtar Kelimeler: Kıbrıs, Uygur, masal kahramanları, olumsuz ileti, çocuk eğitimi.

\footnotetext{
* Bu makale, Prof. Dr. Mehmet Aça danışmanlığında Burak Gökbulut tarafından tamamlanan Kıbrıs Türk Masalları ile Uygur Türk Masalları Üzerinde Karşılaştırmalı Bir Araştırma (İnceleme-Metinler) başlıklı Doktora tezinden üretilmiştir. 


\title{
Negative Messages Conveyed in the Context of Cyprus and Uyghur Turkish Tale Heroes in terms of Education
}

\begin{abstract}
After the conquest in 1571, the Turks who were placed in Cyprus continued to struggle for their existence in the last century. After being subjected to a great oppression and persecution, they founded the TRNC on 15 November 1983 with a great support of Turkey. The other Turkish noble state involved in the study is East Turkestan, where approximately 24 million Uyghur population are located. East Turkestan is a country that has very important economic resources but cannot use them properly due to the pressure and politics of China. When we look at the literary and oral cultural products of the nations, we clearly see the reflection of the social-political events they have experienced. In this sense, it is very important to examine the verbal products of both nations in every aspect. As one of these oral products, the tale can be defined as a type of oral, anonymous folk literature, giving advice and lecturing in one subject, having functions such as educating children, including formal elements, motifs and descriptions, and possessing a clear, plain language and expression but not a specific and certain time and place. The educational function of the tales is a particular issue to be emphasized. Because it is necessary to choose the tales to be used in child education carefully. In our work, we tried to show and examine the negative elements in the tales of both Turkish societies by evaluating their heroes. From the educational perspective, it is possible to list some negative elements for children in the Turkish Cypriot folk tales as follows: Death, violence, jealousy, greed, lying, immorality, begging, breaking a promise and so on. We encountered the following negative elements in the Uyghur Turkish folk tales that we had reviewed: Bribery, greed, lying, theft, opium use, curse, death, and so on. With reference to the negative elements in and plotlines of the tales that we have examined, it is possible to state that the Uyghur Turkish folk talks are weaker than the Turkish Cypriot folk tales in terms of educational quality.
\end{abstract}

Keywords: Cyprus, Uyghur, tale heroes, negative message, child education. 


\section{GíRiş}

Anadolu Türk halk masallarıyla genel özellikleri bakımından benzeyen ve bu saha ile birçok ortak varyantı bulunan Kıbrıs Türk halk masalları, geleneksel manadaki sözlü anlatım bağlamını yitirmiş durumdadır. Artık masalların birçoğu sadece masal kitaplarında bulunan metinlerden ibarettir.

Uygur Türk halk masalları da yapı, içerik ve işlev bakımından Kıbrıs Türk halk masallarıyla bazı ortak özellikleri taşımaktadır. Masalların işlevsel özelliklerine baktığımızda bunların ahlakî, sosyal ve psikolojik eğitim; dil öğretimi, öğüt ve ders verme gibi görevleri üstlendiği görülmektedir. Yine Bilkan'ın (2001: 7) dediği gibi masallar hem çocukların ruhunun beslenmesinde, hem hayal güçlerinin geliştirilmesinde hem de onların dil eğitimlerinde etkilidirler. Çocukları okumaya yönlendirmede, güzel konuşma becerisi kazandırmada, ahlâkî değerleri öğretmede, geçmiş bilincini aşılamada, düşünce ve ifade yeteneklerini geliştirmede vb. etkilidirler. "Masal, bir yandan çocukların düşünce ve hayal dünyalarını zenginleştirirken bir yandan da onların kazanması gereken iyilik, dürüstlük, çalışkanlık ve yardım severlik gibi erdemlerin olaylar içinde edinimini sağlamaktadır." (Karatay 2007: 471).

Esma Şimşek'e göre de "Masal dinleyicilerini, iyilik yapmaya teşvik etmekte ve masallar eğiticilik ve ders verme özelliklerini barındırmaktadır." (Şimşek 2001: 5). Yine hayvan masalları konusunda değerli çalışmalar yapan Ali Berat Alptekin'e göre "Hayvan sevgisi olmayan bir kimsede, insan sevgisi de olmaz. Bu sebepten çocuk, hayvanları sevmeyi, masallarda öğrenmekte ve geleceğinin şablonunu daha ilk dinlediği metinde kendi kafasında kurmaktadır." (2005: 28).

Ancak masallar çocukların eğitiminde kullanılırken çok dikkatli olunmalı ve bunlar özenle seçilmelidir. Çünkü masallar birçok sakıncalı ve zararlı unsuru da içinde barındırabilmektedir. Masal türü bir yandan içerdiği ögütlerle akıcı ve sade diliyle, hayalî unsurlarıyla vb. çocuk gelişimine olumlu yönde katkıda bulunurken, diğer yandan da barındırdığı birtakım olumsuz unsurlarla çocuk gelişimine zarar verebilmektedir. Çalışmadaki masal incelemelerine bakıldığı zaman da bu kolaylıkla anlaşılabilir. Bazı masallarda şiddet, korku, cinsellik, ahlâksızlık, adaletsizlik, kötü ve çirkin davranışlar vs. bulunmakta ve bu da masalı okuyan veya dinleyen çocuğa gerçek manada zarar vermektedir. Helimoğlu (2002: 70-90) da çalışmasında masalların eğitimsel işlevlerinden geniş şekilde bahsetmekte ancak kötü davranışlar sergileyen birçok kahramanın da masallarda yer aldığını belirtmektedir. Örneğin; kıskanç, iftiracı, yalancı, kurnaz kadınlar, kötü kalpli üvey anneler, büyücü kadınlar ve dev anaları, eşlerini aldatan kadınlar; açgözlü, hilekâr, kötü yürekli erkekler vb. Yine yazara göre cinsel taciz, işkence gibi kötü olaylar da masallarda yer bulmaktadır.

\section{Çalışmanın Amacı:}

Araştırmada Uygur ve Kıbrıs Türk halk masallarının kahramanları bağlamında iletilen olumsuz mesajların tespit edilip incelemesi ve karşılaştırılması amaçlanmaktadır. $\mathrm{Bu}$ amaçla aşağıda verilen soruların cevapları aranmıştır:

1. Uygur ve Kıbrıs Türk halk masal kahramanları ile bunlar üzerinden iletilen olumsuz mesajlar nelerdir?

2. Uygur ve Kıbrıs Türk halk masallarıyla iletilen olumsuz mesajlardaki benzerlik ve farklıliklar nelerdir?

SEFAD, 2017 (38): 307-324 


\section{Çalışmanın Yöntemi:}

Çalışmamızda araştırma yöntemi olarak nitel araştırma uygulanmış ve verileri toplamak amacıyla doküman analizi kullanılmıştır.

\section{Çalışmanın Örneklemi:}

Çalışmanın evrenini Uygur ve Kıbrıs sahası Türk halk masallarının tümü oluştururken örneklem, amaçlı örnekleme yöntemiyle seçilen her iki alandan 10'ar masalı (toplamda 20 masal) içermektedir. Amaçlı örneklemenin bir türü olan kolay ulaşılabilir örneklemesi bu çalışmada temel alınmış, böylelikle araştırmacıların önceden incelediği, bilgi sahibi olduğu ve içinde olumsuz mesajların bulunduğunu düşündüğü 10'ar masal tercih edilmiştir. Uygur Türk masalları Uygur Türkçesi alfabesinden (Arap Alfabesi kaynaklı) Latin harflerine aktarılırken Ortak Türk Alfabesi (Ercilasun 1997: 135-139) kullanılmıştır.

Uygur Türk halk masalları Tursun Letip-Hocahmet Yunus'un (1982), Mirkamil Yakup-Hesen Eli'nin (1982) ve Nurmuhemmet Zaman-Turgan Şavdun'un (1982) Uygur Helk Çöçekliri adlı kitaplarından alınmıştır.

Kıbrıs Türk halk masalları Oğuz Yorgancıoğlu'nun Kıbrıs Türk Folklorundan Derlemeler-Masallar I (1988) ve Kıbrıs Türk Folklorundan Derlemeler-Masallar II (2006) adlı kitaplarından alınmıştır.

\section{Veri Toplama ve Analiz Yöntemi:}

Çalışmanın verileri Uygur ve Kıbrıs Türk halk masallarıyla ilgili olarak yayınlanmış olan farklı masal kitaplarından toplanmış ve incelemede 10 Uygur 10 Kıbrıs Türk halk masalı kullanılmıştır. Araştırmada "betimsel analiz" yoluyla masallar çözümlenmiş, öncelikle olay örgüsü özetlenerek sunulmuş, ardından olumsuz mesajlar tematik bir çerçevede yorumlanarak verilmiştir.

\section{BULGULAR}

\section{A. Kibris Masallari:}

Kıbrıs Türk halk masalları üzerine önemli çalışmaları bulunan yazar Oğuz Yorgancığlu'nun masallarla ilgili iki ciltlik çalışması bu sahadaki orijinal masal metinlerini içeren önemli kitaplardır. Yazarın Kıbrıs Türk halk bilimi ve edebiyatı alanında çok çeşitli ve önemli çalışmaları bulunmaktadır. Bu çalışmalar arasında Kıbrıs Türk Folkloru, manileri, ninnileri vs. ile ilgili çalışmalar yer almaktadır.

\section{Padişahınan Gızları Masalı (Yorgancıŏglu 2006: 87-89)}

Olay Örgüsü: Masalın başında saray bahçesine bir sopa düşer, padişah falcı çağırarak ona bunu yorumlamasını söyler. Falcı yorumlamak için üç gün süre ister. Falcının rüyasına giren aksakallı bu durumu ona yorumlar, o da padişaha giderek üç kızına ok öğretip ok attırmasını ve okun düştüğü yerdeki oğlanlarla kızlarını evlendirmesini söyler. Kızlar ok atmayı öğrenir ve okları atarlar. İki kızın oku baş vezirin ve vezirin avlusuna düşer, en küçük kızın oku da bir boynuzun üzerine düşer. İki kız evlenir. Oku boynuza düşen kızsa sarayda kahır. Büyüyle boynuza hapsedilen yakışıklı oğlan her gece kızla görüşür ama kıza bundan hiç kimseye bahsetmemesini söyler. Bir gün ülkede bir düğün yapılır, ancak yakışıklı oğlan sevgilisine dügüune gelmemesini söyler. Kız buna rağmen üç kez düğüne gelerek sevgilisini izler. Ama üçüncü kez dügündeki ablalarına yakışıklı prensin kendi sevdiği olduğunu söyler. Bunun üzerine sırrı açığa çıkan yakışıklı oğlan bulutlara yükselir. 
Kız kaçan sevgilisini aramak için yollara düşer, sevdiği yakışıklı oğlanı bulur ve saraya dönerek evlenirler.

Masalda Verilmek İstenen Mesaj: Masalda, ulaşılmak istenen güzel şeyler için sabredilmesi ögüutlenmiş ve masal mutlu sonla bitmiştir. Bununla birlikte masal bir bütün olarak değerlendirildiğinde içerisinde çocukların eğitimi açısından kötü örnek oluşturabilecek kahramanlar ve onlar aracılığıyla çocuklara iletilen davranışlar göze çarpmaktadır.

Masal Kahramanları ve Olumsuz İletiler: Masaldaki kahramanlar arasında padişah, falcı, padişahın üç kızı, boynuzdan çıkan yakışıklı oğlan, peri ve yaşlı komşu bulunmaktadır. Masaldaki iyi kahramanlar küçük kız ve yakışıklı oğlandır. Padişah ise duruma göre sert tavrını ortaya koyan iyi bir hükümdardır. Kötü kahramanlar ise kızın iki ablasıdır. Masaldaki olumsuz iletiler de bu iki kahraman üzerinden verilmektedir. Masaldaki olumsuz iletiler iki ablanın küçük kız kardeşlerine "Sen git al boynuzu da k.çına sok." demesi ve eş ararken okunun bir boyunuza çakılması ile ilgili kardeşleriyle alay etmeleridir. Bu tür küfürlü sözler çocuğun ahlakî gelişimini kötü yönde etkileyebilir. Ayrıca ablalarının küçük kız kardeşlerini kıskanmaları ve sevmemeleri de kötü davranışlardır.

Masalın başında padişah, falcıya rüyasının yorumu için üç gün vermiş ve "-Yoksa kellen gider." demiştir. Bu söz şiddet içeren olumsuz bir iletidir.

Boynuzdan çıkan yakışıklı adamın küçük kıza "sakın bunu kimseye belli etme ve söyleme" demesine rağmen kızın sözünde durmaması ve bunu söylemesi de doğru bir davranış değildir ve kahramanın gönderdiği olumsuz bir mesajdır.

Masalın sonunda iki ablanın kötü davranışları adına bir ceza almamaları da olumsuz iletileri bir bakıma pekiştirmektedir.

2. Dürdane Masalı (Yorgancioğlu 2006: 111-112)

Olay Örgüsü: Masalın girişinde padişah sefere çıkacağı zaman kızlarına ne hediye istediklerini sorar. İki büyük kız ne istediğini belirtir ancak en küçük kız babasına gönlünden ne koparsa onu almasını söyler. Böyle olunca en güzel hediye hep en küçük kız Dürdane'ye gelir. Kız kardeşlerini kıskanan ablaları Dildane ile Güldane onu öldürüp avlunun uzak yerine, bir fesleğen çiçeğinin yanına gömerler. Padişah yine bir sefer dönüşü geldiği zaman Dürdane'yi bulamaz. Bu arada avluda çobanın koyunları otlanır ama bütün otları yemelerine rağmen fesleğen çiçeğini yemezler. Fesleğenin neden yenmediğini merak eden çoban gidip fesleğenden bir dal koparır ve çiçek inleyerek kendisinin Dürdane olduğunu söyler. Çoban gidip padişaha olanları anlatır. Padişah iki büyük kızının küçük kızını öldürdügüüü anlar. Padişah iki kızı evlendirip saraydan kovar ve sarayda yalnız kalan padişah ölür.

Masalda Verilmek İstenen Mesaj: Kıskançlığın kötü bir davranış olduğu düşüncesinin başarıyla işlendiği masalın sonunda yanlış yapan padişah ve iki kızı cezalandırılmıştır. Ancak bazı kahramanların olumsuz davranışları açısından masalın çocuklara doğrudan verilmesinin uygun olmadığını söyleyebiliriz.

Masal Kahramanları ve Olumsuz İletiler: Dürdane masalının kahramanları arasında padişah, onun karısı ve üç kızı (Dildâne, Güldâne, Dürdâne), çoban, hizmetkâr ve padişahın adamları bulunmaktadır. Bu kahramanlardan padişah, çoban ve Dürdâne iyi, Dildâne ve Güldâne ise kötü kahramanlardır. Buradaki olumsuz mesaj iki kız kardeşin kıskançlıktan dolayı en küçük kız kardeşlerini öldürmeleridir. Aşırı kıskançlık duygusu masalı okuyan/dinleyen çocuğun sosyal (kardeşlik vs.) ilişkilerini zedelerken, öldürme davranışı da çocuğun psikolojik gelişimine zarar verebilir. Olaylar sonucunda kardeşlerini öldüren 
ablalar padişah tarafından evlendirip saraydan gönderilirler ancak bu ceza öldürme davranışının yanlışlığını gösterecek kadar büyük değildir. Masalı okuyan/dinleyen çocuk bazı sebepler göstererek birini öldürmenin çok da yanlış bir davranış olmadığını ve cezalandırılmayacağını düşünebilir.

3. Dünya Güzeli Masalı (Yorgancığlu 1998: 89-92)

Olay Örgüsü: Masalın başında padişahın tek kızı vezirin oğlu ile evlenir. Vezirin oğlu sefere çıkmadan önce iki çocuğunun olacağını öğrenir ve kaynanasından çocuklara bakmasını ister. Gelinini sevmeyen kaynana ebeyle anlaşarak yeni doğan iki çocuğu sandığa koyar ve dere yatağına bırakır. Gelininin yanına da iki küçük köpek yavrusu koyarak oğlunu "Senin eşin köpek doğurdu." diyerek kandırır. Vezirin oğlu başta annesinin sözüne inanır ve eşini bir yere hapsederek gelenin geçenin yüzüne tükürmesini sağlar ancak masalın sonunda padişah gerçekleri öğrenir, vezirin annesini ve ebeyi cezalandırarak, ailesiyle mutlu bir şekilde yaşar.

Masalda Verilmek İstenen Mesaj: Kötülük edenlerin mutlaka bir gün cezalarını çekeceği düşüncesi masalda başarıyla işlenmiştir.

Masal Kahramanları ve Olumsuz İletiler: Masalın ön planda yer alan kahramanları arasında padişah, padişahın kızı, vezirin oğlu, kaynana, ebe ve iki çocuk bulunmaktadır. Masalda yer alan ebe ve kaynana kötü kahramanlardır. Söz konusu kötü kahramanlar masalın sonunda cezalandırılmış ve çocuklara yukarıda bahsettiğimiz olumlu düşünce iletilmiştir. Bununla birlikte masalı bütünüyle okuduğumuzda içerisinde çocuklar açısından sakıncalar içerebilecek bazı sözcükler olduğunu görüyoruz. İncelemiş olduğumuz bu masalın "p.ç, sıç..." vb. argo sözcüklerden arındırıldığı takdirde belli bir yaş grubundaki çocuklar için uygun olacağını düşünüyoruz. Bunların yanında masalda yer alan diğer olumsuz iletiler arasında kaynananın gelinini kıskanıp ona kötülük yapması, çocukların ebe tarafından dereye atılması ve adamın annesinin sözüne şartsız inanarak eşini hapsetmesi bulunmaktadır.

\section{Fatmacığnan Yusufcuk Masalı (Yorgancıŏ̆lu 1998: 61-63)}

Olay Örgüsü: İki çocuklu dul kadının ikinci kocası ava gider ve avladıklarını kadına getirir. Kadın avları kediye kaptırır. Kocası anlamasın diye memesini keserek pişirir. İkinci gün yine avı kaptırır ve diğer memesini pişirir. Üçüncü gün adamın avladıklarını pişirir, ama bu kez da adam yemeği beğenmez ve kadın ona gerçeği söyler. Adam bunun üzerine kadının çocuklarını kesip yemek yapmak ister. Bunu duyan kadın çocuklarını evden gönderir ve adam çocukların peşlerine düşer. Yolda giderken erkek çocuk birikintiden su içer ve kuzuya döner. Bu haldeyken şehzade yolda kızı ve kuzuyu bulur. Onları saraya götürür. Şehzade sefere çıkar ve kıza kimseye kapıyı açmamasını söyler. Kız dinlemez ve halayıkla (Afrikalı kadın köle) dışarıya çıkar. Halayık bahçede onu havuzun içindeki balığa atar ve balık onu yutar. Şehzade geri döner ve halayık onu karısıymış gibi karşılar. Şehzade havuzdaki balığın karnını yarar ve karısı ile oğlunu orada bulur. Şehzade bunun üzerine halayığı cezalandırır ve mutlu yaşarlar.

Masalda Verilmek İstenen Mesaj: Kötülük eden kişilerin günün birinde mutlaka cezalarını çekecekleri düşüncesi masalda işlenmiş ve masal mutlu sonla bitmiştir. Bununla birlikte metnin bütünü incelendiğinde içerisinde yer alan olumsuz kahramanlar (üvey baba ve halayık) aracılığıyla çocuklar açısından zararlı olabilecek birtakım davranışların masalda yer aldığı görülmektedir. 
Masal Kahramanları ve Olumsuz İletiler: Masalın kahramanları kadın ve iki çocuğu (Fatmacık, Yusufcuk), üvey babaları, padişahın oğlu, halayık ve Fatmacığın oğludur. Masaldaki iyi kahramanlar kadın, Fatmacık, Yusufcuk ve padişahın oğludur. Kötü kahramanlar ise halayık ve üvey babadır.

Masaldaki ilk olumsuz ileti kadının memesini kesip duruma çare bulmasıdır. Ancak bu tür bir içerik çocukların psikolojisine olumsuz etkiler yapabilir. Diğer taraftan kötü kahraman üvey babanın üvey çocuklarını kesip yemek istemesi de olumsuz bir iletidir. Halayığın kadını bahçedeki havuzun içindeki balığa atıp onu yutturması da diğer bir olumsuz davranıştır. Tüm bunlar olumsuz ve şiddet içeren unsurlar olarak göze çarpmaktadır.

5. At-Kurt-Adam Masalı (Yorgancioğlu 2006: 184-185)

Olay Örgüsü: Memleketin birinde bembeyaz güzel bir at vardır. Bu at bir gün yaşadığı bölgede tanımadığı bir hayvan görür ve korkar. Bu dişli hayvan günden güne ata yakınlaşmaya başlamış. At diğer hayvanlardan bunun kurt olduğunu öğrenir. Diğer hayvanlar "Bunun çaresini ancak adam (insan) bulabilir." der. At, meranın yanında bulduğu adama derdini anlatır. Adam ata "İkimiz birlik olursak kurdu yeneriz." der. Adam ata eyer ve yular takarak onu insan taşımaya alıştırır; böylece kurdu yakalayabileceklerdir. Adamın üstüne binmesini kabul eden at, ertesi gün adamla birlikte kurdu bulmaya gider. Adam atın üzerinde hızla giderek kurdu mızraklayıp öldürür. At hemen uyan ile eyerden kurtulmak ister. Adam da ortaklığımız daha yeni başladı deyip ata binmeye devam eder.

Masalda Verilmek İstenen Mesaj: Birlikten kuvvet doğar düşüncesinin işlendiği masalda çocuklara her zaman yardımlaşmaları öğütlenmiş ve masal mutlu sonla bitmiştir.

Masal Kahramanları ve Olumsuz İletiler: Masaldaki kahramanlardan at ve adam iyi kahramanlar, kurt ise kötü kahraman olarak yer almaktadır. Masaldaki olumsuz ileti adamın kurdu öldürdüğü sahnedir: "Tepeye varmadan adam kurdu mızraklamış. Kanları fışkıran kurt, orada can vermiş." Kurt masalın kötü kahramanı olduğu için masalda adamın kurdu öldürmesi olumlu bir şeymiş gibi gösterilir. Oysa öldürme gibi şiddet içeren bir unsur özellikle belli yaş grubundaki çocuklar için oldukça sakıncalıdır ve olumsuz iletiler içerisinde yer almaktadır.

6. Beddualı Çocuk Masalı (Yorgancıŏ̆lu 2006: 23-25)

Olay Örgüsü: Çocuksuzluk çeken padişah ve karısı buna çare bulmak için vezirlerini başka memleketlere gönderirler. Vezirler buna bir türlü çare bulamaz ve memleketlerine geri dönmeye karar verirler. Geri dönerken yolda karşılaştıkları peri onlara çocuk sahibi olmayı sağlayacak bir elma verir ve hem kadın hem yavrusuz bir at hamile kalır. Padişah, çocuk erkek olmazsa onu öldüreceğini söyler. Kadın bir kız çocuk doğurur, ama erkek doğurduğunu söyler. At da bir dişi tay doğurur, adını Gamer koyarlar. Gamer ve padişah kızı beraber büyüdügü için birbirleriyle konuşabilirler. Çocuk on iki yaşına gelince padişah onu oğlan bildiği için sünnet ettirmek ister. Bir süre sünneti ertelerler, ancak sonunda kız ile Gamer memleketten kaçarlar. Diğer memleketin askerleri kız ile atı yakalayıp padişaha götürürler. Buradaki padişahın kızı oğlana (aslında kızdır) âşık olur. Padişah oğlana (aslında kıza) kızıyla evlenmek için üç şartı yerine getirmesi gerektiğini söyler. Oğlan üç şartı da yerine getirip Gamer'in annesi olan hızlı at ile saraya geri dönerken devlerden biri Gamer'in annesinin kuyruğunu yakar. Bunun üzerine hızlı at kıza beddua eder: "Erkeksen kız, kız isen erkek ol!" Beddua üzerine kız, erkeğe dönüşür ve böylece padişahın kızı ile evlenir. Oğlan, eşi ve atı Gamer'i de alarak ülkesine döner. Oğlanın geldiğini gören annesi onu hâlâ 
daha kız zannettiği için çok korkar. Oğlan erkeğe dönüştüğünü annesine söyler, annesi çok sevinir. Oğlan kendi memleketinde kırk gün kırk gece dügün yapar ve mutlu şekilde yaşarlar.

Masalda Verilmek İstenen Mesaj: Masalda gerçekleşmesi istenen şeyler için usanmadan çalışmak gerektiği düşüncesi işlenmiştir. Masalın sonu mutlu bitmiş ve çocuklara mesaj başarıyla ulaştırılmıştır.

Masal Kahramanları ve Olumsuz İletiler: Masaldaki kahramanlar kızın babası olan padişah, onun eşi ve padişahın erkeğe dönen kız çocuğu, vezirler, ebe, peri, atın yavrusu Gamer, ağzından ateş saçan dev, kız çocuğunu bulan diğer padişah ve onun oğludur. Masaldaki iyi kahramanlar erkeğe dönen kız çocuğu, diğer padişah ve oğlu, vezir ve Gamer'dir. Kötü kahraman ise kızın babası olan padişahtır.

Padişahın kız çocuğu istememesi ve kız çocuğu olursa öldüreceğini söylemesi yanlış bir düşüncedir ve masalı dinleyene/okuyana olumsuz bir mesaj gönderir. Kız çocuğuna karşı geliştirilen bu yanlış tutum eğitim açısından kesinlikle çok sakıncalıdır. Bu gibi masal metinlerinin çocuğa verilmesi ileride oldukça tehlikeli sonuçları beraberinde getirecektir. Kız çocuğunun değersizleştirilmesi insan hakları ve toplumun ilerlemesi açısından yanlıştır. Ama masalda bu yanlışlık üzerinde durulmaz. Sadece kız, erkek gibi büyütülür ve sonunda beddua ile erkeğe dönüşerek evlenir. Bu durumdan kurtulmak isteyen anne ile kız çocuğunun yalan söylemesi ve kızın ortadan kaybolması da her ne kadar kurtuluşu sağlasa da doğru bir davranış değildir ve zor durumda kalan çocuklara "Zor durumda yalan söylenebilir." gibi yanlış bir mesaj gönderir. Masalda Gamer'in annesi olan atın, kıza beddua etmesi de eğitimsel açıdan sakıncalı görülebilir.

\section{Gadife Masalı (Yorgancioğlu 2006: 196-197)}

Olay Örgüsü: Kadın öleceği zaman kocasına vasiyet bırakır. Vasiyete göre kadının bileziği hangi kadına uyarsa adam onunla evlenecektir. Kadın öldükten sonra bilezik sadece adamın kızının bileğine uyar. Adam kendi kızıyla evlenmek ister. Bunun üzerine kız kilitli bir sandık yapıp kaçar. Atlı bir adam onu yolda bulur ve sandığı alıp sarayına götürür. Kız uzun zaman sandıktan çıkmaz. Bir düğün gecesi oğlanın yanına gider ve oğlan ona bir yüzük takar. Sonra kız tekrar sandığa gizlenir. Adam kızın sandıktaki kız olduğunu bilmez bu yüzden onu aramak için yollara düşer. Kız, adamın yolda yiyeceği peksimetin içine yüzügünü saklar. Adam yolda yemeğe dururken bu yüzüğü bulur ve aradığı kızın sarayda olduğunu anlar. Bunun üzerine saraya dönen adam sandığı parçalar ve düğünde gördüğü kızın o olduğunu anlar. En sonunda kızla oğlan evlenirler.

Masalda Verilmek İstenen Mesaj: Masalda, yanlış olduğunu düşündüğünüz işleri yapmayınız mesajı verilmiş ve masal mutlu sonla bitmiştir. Bununla birlikte masalın içerisinde kötü kahramanlar aracılığıyla çocukların eğitimi açısından onaylayamayacağımız davranışlar sergilenmiştir.

Masal Kahramanları ve Olumsuz İletiler: Masaldaki kahramanlar adam, onun karısı ve kızı (Gadife) ile padişahın oğludur. Bu masalda olumsuz karakter Gadife'nin babasıdır. Masalda baba, eşinin vasiyeti üzerine bileziğin sahibi olan kişiyle evlenmek için bileziğin uyduğu kişiyi arar ve sonunda öz kızının bileğine uyduğunu görür. Bunun üzerine kendi kızıyla evlenmek istemesi tamamen yanlış bir davranıştır. Masalın sonunda adam bu kötü davranışla ilgili herhangi bir ceza almamıştır. 
8. Cadaloz Masalı (Yorgancıŏ̆lu 2006: 178-180)

Olay Örgüsü: On üç tane yaramaz çocuğu olan fakir kadın günün birinde haftalık ekmek yapmak için hamur yoğurur. Kadın taş fırını yakana kadar bu yaramaz çocuklar bütün hamuru etrafa saçıp mahvederler. Bunu gören kadın sinir anında çocukların on ikisini de fırında yakar on üçüncü çocuk ise un küpüne saklanıp kurtulur. Kadının siniri geçince yaptığından çok pişman olur ve ağlamaya başlar. Annesinin ağlamasına dayanamayan çocuk dışarı çıkar. Kadın eşine çocukla yemek gönderir. Çocuk yemeği getirdikten sonra babasını beklerken öküz üzerine pisler. Babası onu temizlenmesi için çeşmeye gönderir, ama suyun çıktığı yere bakma der. Çocuk yıkanıp incir ağacına incir yemeye çıkar. Bu arada bir kocakarı gelip incir ister ve çocuğu heybesine atar. Aslında kocakarı çocukları yiyen bir cadalozdur (cadı) ve çocuğu heybesinde eve götürür. Cadaloz evdeki hizmetkâra çocuğu pişirmesini söyler ve gider. Hizmetkâr çocuğu kesmeden çocuk hizmetkârı keser ve hizmetkâr kızın kılığına girer. Cadaloz kız kılığındaki oğlanı yıkamaya götürdüğünde ise onun hizmetkârı olmadığını anlar. Çocuk o anda satırı kapıp kaçmaya başlar. Peşine düşen cadalozun ensesine satırı vurup onu öldürür ve kurtulur.

Masalda Verilmek İstenen Mesaj: Masalda çocuklara, anne ve babalarının sözlerini dinlemedikleri takdirde hayatlarının tehlikeye gireceği düşüncesi çok fazla olumsuz unsur ve davranışla anlatılmak istenmiştir.

Masal Kahramanları ve Olumsuz İletiler: Masaldaki kahramanlar kocakarı, kocası ve on üç çocuğu, cadaloz ve onun hizmetkârıdır. Masaldaki iyi kahramanlar ölümden kurtulan çocuk ve babasıdır. Kötü kahramanlar ise kocakarı, cadaloz ve hizmetkârdır.

Masalda, annenin çocuklarını öldürmesi kötü bir davranıştır. Kadının bu kötü davranışı masalda cezalandırılmaz. Bunun yanında cadalozun çocuğu pişirmek istemesi, çocuğun hizmetkârı kesip öldürmesi, çocuğun cadalozun ensesine satırı vurup onu öldürmesi vb. daha birçok olumsuz ileti masalda geniş yer tutmaktadır.

9. Gabak Gız Masalı (Yorgancıoğlu 2006: 155-157)

Olay Örgüsü: Fakir bir karı koca dilenmeye çıkar. Dilenerek giderken bir bahçenin önüne gelirler. Bahçeci onlara kırmızı bir kabak verir. Eve gelip kabağı mutfağa koyarlar. Ertesi gün un dilenmeye giderler, ama un bulamazlar. Eve döndüklerinde, evin tertiplenmiş yemeklerin hazırlanmış olduğunu görürler. Bu böyle sürer ve komşularına da yemek dağıtmaya başlarlar. Bu haber padişahın oğlunun kulağına da gider. Padişahın oğlu kıyafet değiştirerek bu eve gelir ve bunun doğru olduğunu görür. Şehzade, kadınla adama bir konak ve biraz altın vererek kırmızı kabağı alıp saraya götürür. Şehzade kabağı alıp mutfağa koyar, kendi de dolaba saklanır. Gece olunca kabaktan çok güzel bir kız çıktığını görür. Üçüncü gece kız kabaktan çıkınca şehzade kabağı parça parça eder ve kız kabağa geri giremez. Şehzade kız ile evlenmek ister. Kız bir peri olduğunu söyler ve şehzadeye, periyle evlenip evlenmeyeceğini sorar. Şehzade ve kız beraber yaşamaya başlarlar. Padişah bunu duyup kıskanır ve gidip aynı ihtiyardan bir kabak alır. Ancak bu kabaktan bir kız çıkmaz ve padişah kabağı paramparça eder. Diğer taraftan şehzade ile kabak kız düğün yapıp evlenirler.

Masalda Verilmek İstenen Mesaj: Masalda kıskançlı̆̆ın kötü bir şey olduğu ve kıskanç insanların hayatta hiçbir zaman istediklerini elde edemeyecekleri mesajı verilmek istenmiştir.

Masal Kahramanları ve Olumsuz İletiler: Masaldaki kahramanlar ihtiyar adam, kocakarı, komşular, kabaktan çıkan peri kız, padişah ve padişahın oğlu, altı oğlan altı kız 
çocuğudur. Masaldaki iyi kahramanlar padişahın oğlu, ihtiyar adam, kocakarı, komşular ve kabaktan çıkan peri kızdır. Kötü kahraman ise padişahtır.

Mutlu sonla biten masalda karı-kocanın dilenmeleri çocukları olumsuz anlamda etkileyecek sakıncalı davranışlardan biridir. Bunun dışında padişahın, oğlunu kıskanarak kabak satın alması ve daha sonra kabakların içerisinden peri çıkmayınca onları parçalaması da çocukların eğitimi açısından oldukça sakıncalıdır. Masaldaki olağanüstü olaylardan biri de kabağın içerisinden çıkan peri kızdır. Kabağın içerisinden kızın çıkması da belli yaş grubundaki çocuklar için korkutucu olabilir. Dolayısıyla değerlendirmiş olduğumuz metin uygun yaş grubundaki çocuklara verilmeli ve birtakım olumsuz unsurlardan arındirılmalıdır.

10. Padişahın Elma Ağacı Masalı (Yorgancıŏ̆lu 1998: 31-34)

Olay Örgüsü: Padişahın elma ağacındaki elmalar olgunlaştığı zaman birileri gelip elmaları keser. Padişah oğullarını çağırır ve elmaları kimin çaldığını öğrenmelerini ister. Büyük oğlan ağaç başında nöbet tutmaya karar verir. Gece yarısı bir gürültü patırtıyla elmalar kaybolur, ama oğlan kimin topladığını anlayamaz. Ertesi gece ortanca oğlan nöbet tutar, ama o da kim olduğunu göremez. Sıra en küçük oğlana gelir. Küçük oğlan yanına Kur'an-1 Kerim'i de alır ve birkaç sure okur. Gece yarısı bir gürültü duyulur. Oğlan rastgele kılıcını sallar ve kılıç hırsızı yaralar. Ertesi sabah gidip baktıklarında elmanın altından başlayan kan izlerinin bir kuyuda son bulduğunu görürler. İlk önce büyük oğlan kuyuya salkıtılır. Ancak dibe inmeden yandım dediği için yukarı çekerler. Ortanca oğlan da kuyu dibine inemez. Küçük oğlan yandım desem de beni indirin der. Böylece küçük oğlan kuyu dibine kadar iner. Küçük oğlan dibe inince üç kapı görür. Oğlan birinci kapıyı açar. Devin kucağında bir kız görür ve devi öldürür. Oğlan ikinci ve üçüncü odadaki devleri de öldürür ve kızları yukarıya yollar. Küçük kız oğlana ceviz, badem ve fındık içinde gelinlik ile iki tüy verir. Oğlan yukarı çıkarken kardeşleri ipi keser ve oğlan kuyuda kalır. Oğlan tüylerden birini yakar ve beyaz koç yerine yanlışlıkla kara koça biner ve yeraltına iner. Yeraltında bir mahallede dolaşırken tükürügüyle hamur yoğuran bir kocakarı görür. Oğlan bu kez derenin suyunu kesen devi öldürür. Oğlan yoluna devam eder. Üzerinde üç yavru kuş olan ağacın altına oturur. Oğlan yavruları yemeye gelen yılanı öldürür. Bu yüzden ana kuş oğlana yardımcı olur ve onu yeryüzüne çıkarır. Oğlanın ağabeyleri evlenir. Küçük oğlan da küçük kızla evlenir ve padişah tahtını ona devreder.

Masalda Verilmek İstenen Mesaj: Masalda, iyi insanların her zaman kazanacağ ögüt olarak verilmiş ve masal mutlu sonla bitmiştir. İncelemiş olduğumuz metin eğitimsel açıdan belli bir yaş grubundaki çocuklar için uygun olsa da içerisinde bulunan birçok olumsuz unsurun çıkarılarak tekrar düzenlenmesi gerekmektedir.

Masal Kahramanlanı ve Olumsuz İletiler: Masaldaki kahramanlar padişah ve üç oğlu, kuyudaki üç kız ve üç dev, yeraltındaki nine ve padişahın kızı, yardımcı kuş, terzi başı ve üç kızıdır.

İki kardeşin, en küçük kardeşi kıskanıp kuyuda bırakması kötü bir davranıştır. Kıskançlık duygusuyla insanlara zarar verilmesi çocuğu da kötü yönde etkileyebilir. Kılıçla birinin yaralanması, "kan izi" sözünün geçmesi ve yavruları yemeye gelen yılanın öldürülmesi şiddet içerikli unsurlardır. 


\section{B. Uygur Masalları:}

Doğu Türkistan'da masallarla ilgili olarak yürütülmüş olan kapsamlı derleme faaliyetleri sonucunda geniş bir masal külliyatı elde edilmiş ve bu derlenen masallar ciltler halinde yayınlanmıştır. Yayınlanan masal kitaplarının on iki cildi elimizde mevcuttur. Uygur Türk halk edebiyatı ve masalları konusunda önemli çalışmaları bulunan Tursun Letip, Hocahmet Yunus, Mirkamil Yakup, Hesen Eli, Nurmuhemmet Zaman ve Turgan Şavdun'un "Uygur Helk Çöçekliri" adlı kitapları Uygur sahasındaki büyük bir boşluğu doldurmuş önemli çalışmalardır.

1. Bay Bilen Qazi (Zengin ile Kadı) (Letip-Yunus 1982: 81-82)

Olay Örgüsü: Fakir bir çobanın kuzusunu çalan zengin adam kadıya sığınır ve kendisini savunmasını ister. Kadı da rüşvet karşıllı̆ında zengin adamı savunarak, onun böyle bir şey yapmayacağını söyler ve zengin adama iftira atılmamasını buyurur. Çoban da "Hırsızı destekleyen de imansızdır." diyerek kadı'nın evinden ayrılmak zorunda kalır. Bu sözü duyan kadı'nın dili tutulur ve kekeme olur.

Masalda Verilmek İstenen Mesaj: Masalda çocuklara hırsızlı̆̆ın ve rüşvetin kötü bir davranış olduğu verilmek istenmiş ancak söz konusu düşünce tam olarak iletilememiştir.

Masal Kahramanları ve Olumsuz İletiler: Masaldaki kahramanlar çoban, kadı ve zengin adamdır. Çoban masal içerisinde olumlu bir tip, kadı ve zengin adam ise hırsız, yalancı tipler olarak verilmiştir. Masalın sonunda rüşvet alan kadı cezasını çekmiş ve kekeme olmuştur. Ancak hırsızlık yapan ve rüşvet veren zengin adamın herhangi bir ceza aldığını göremiyoruz. Dolayısıyla masalı okuyan çocukların, hırsızlık ve rüşvet vermenin ne derece kötü davranışlar olduğunu fark etmeleri mümkün olmayacaktır.

2. Palta Səpiga Mozay Təzeklidi (Balta Sapına Buzağı Pisledi) (Letip-Yunus 1982: 111-113)

Olay Örgüsü: Sadirahun isminde yoksul birisi Nametmen şehrinin kadısı önünde deva bulmaya gelir ancak kadı, adamı yoksul görünce, rüşvet istediği için, yarın gel der. Olayları komşusuna anlatan Sadirahun, komşusunun tavsiyesi üzerine kadıya hediye vermeyi düşünür ancak yoksul olduğu için bir şey bulamaz ve kutsal kitap Kur'an-1 Kerim ile balta götürmeye karar verir. Kur'an-1 Kerim'i ve baltayı kadıya veren adam, Hoşurbay isminde bir kişinin oğlunu bedavaya çalıştırdığını söyleyerek; ondan yardım ister. Kadı da her ikisini mahkemeye çağırır, Hoşurbay'ın tarafını tutarak "Davayı keseceğim baltanın sapına buzağı pisledi." der ve Sadirahun'u haksız çıkarır. Hoşurbay'ın büyük bir rüşvet verdiğini anlayan Sadirahun mahkemeden ayrılır.

Masalda Verilmek İstenen Mesaj: Masalda çocuklar için herhangi bir olumlu ileti söz konusu değildir.

Masal Kahramanları ve Olumsuz İletiler: Masalın olay örgüsü; Sadirahun, Hoşurbay, Kadı ve Sadirahun'un komşusu üzerine kurulmuştur. Sadirahun ve komşusu masalda iyi, kadı ve Hoşurbay ise kötü kahramanlar olarak verilmiştir.

Masal, zengin insanların rüşvetle her şeyi yapabileceğini göstermektedir. Oysa çocukların masaldan ders çıkarabilmesi için rüşvetin yanlış olduğunun vurgulanması ve bunu yapan kahramanların cezalandırılması gerekirdi.

3. Üç Beñge (Üç Afyon Tiryakisi) (Letip-Yunus 1982: 62-64)

Olay Örgüsü: Çok tembel üç afyon tiryakisi köyün kenarındaki söğüt ağacının altında toplanırlar. Tiryakiler ağaç altında afyon içip sohbet ederken oradan bir çiftçi geçer. 
Tiryakiler çiftçiyi gölgeye davet eder, ama çiftçi onlara gölgenin zararlı olduğunu söyler. Tiryakiler ihtiyar çiftçiyi bu cevabından dolayı alaya alırlar ve sıcakta gölge neden zararlı olsun diye düşünürler. Üç tiryaki yaz aylarını böyle serin yerlerde yatarak geçirirler. Kış geldiği zaman soğuktan donarlar ve bilmeden ahmak dedikleri çiftçinin ekmek tandırının önünde ısınmaya çalışırlar. Çiftçi bunların üç tiryaki olduğunu anlayıp onları içeri alır ve yedirip içirir. Sonunda da onları "Ben yazın alay edip güldüğünüz ahmak çiftçiyim." diyerek utandırır. Tiryakiler utançlarından oradan giderler.

Masalda Verilmek İstenen Mesaj: Masalda tembel insanların her zaman sıkıntı çekeceği vurgulanarak, çocuklara çalışmanın faydaları gösterilmiştir.

Masal Kahramanları ve Olumsuz İletiler: Masaldaki olaylar üç afyon tiryakisi ve çiftçi arasında geçmektedir. Söz konusu metinde afyon tiryakileri tembellik etmenin cezasını çekmiştir. Ancak masalda afyon içmenin kötü bir davranış olduğu hususunda herhangi bir ileti görülmemiştir.

4. Bay Bilen Qoyçi (Zengin ile Çoban) (Letip-Yunus 1982: 262-263)

Olay Örgüsü: Çoban yıllar boyu yanında çalıştığı zengin adamdan parasını alıp ondan kurtulmak ister. Zengin adam da onun yıllar boyu yediği, içtiği ve giydiğini hesaplayıp çobanı borçlu çıkarır ve iki yıl daha çalışması gerektiğini söyler. Çoban bu haksızlığa dayanamaz ve kadıya şikâyete gider. Kadı'nın kâtibi çobana acıyıp, aldığı paranın yarısını kendisine verdiği takdirde bu durumdan onu kurtarabileceğini söyler. Çoban bunu kabul eder. Bunun üzerine kâtip, çobana yargılama yapılırken koyun gibi melemesini gerisini de kendisine bırakmasını söyler. Yargılama günü gelir; kadı çobana derdini anlatmasını söyler ve çoban da koyun gibi meler. Kâtip de "Yirmi yıl bozkırda koyun bakan küçücük çocuk dağda konuşmayı kimden öğrensin?" deyip çobanı savunur. Kadı bunlara inanıp zengin adamdan çobanın yirmi yıllık hakkını almaya hüküm kılar ve çobana parasını verir. Yargılama bittikten sonra çobandan kendi hakkını isteyen kâtibe de çoban meleyip bütün parayı kendine saklar.

Masalda Verilmek İstenen Mesaj: Ele almış olduğumuz bu metinde çocuklar açısından herhangi olumlu bir iletiye rastlamadik.

Masal Kahramanları ve Olumsuz İletiler: Çoban, zengin adam, kâtip ve kadı arasında geçen bu masal çocuklar için oldukça sakıncalı unsurlar içermektedir. Masalda kadı dışında iyi davranışlar sergileyen kahraman bulunmamakta, hatta masalın başında haksızlığa uğradığını düşündüğümüz çoban bile masalın sonunda olumsuz bir davranışla karşımıza çıkmaktadır. Öncelikle çoban, kâtiple birlikte hakkı olan parayı zengin adamdan almak için yanlış bir yola başvurmuş ve mahkemeyi aldatmış, daha sonra kendisine sözde yardımcı olmaya çalışan kişiyi de kandırmıştır.

\section{Qasim Oğri (Hırsız Kasım) (Yakup-Eli 1982: 275-276)}

Olay Örgüsü: Uzun zaman çocuk doğuramayan kadın yedi kız çocuğu doğurur. Kızların babası Hırsız Kasım onları yedi hırsız erkekle evlendirir. Hırsız Kasım kuyumcuya gider ve bir hile yaparak bu altınlar benimdi kuyumcuya satmaya geldiğimde altınlarımı sahiplendi deyip adama iftira atar. Kuyumcu ve Hırsız Kasım kadı'nın önüne çıarlar ve Kasım altınların çoğuna sahip çıkar. Eve döndüğünde bu kez kızları ondan kıyafet ister. Hırsız Kasım pazara kumaş satın almaya gider ve kumaşı seçtikten sonra paramı evde unuttum gidip getireyim, deyip kumaşları çalar. Hırsız Kasım'ın eve getirdiği mallara damatları göz koyar ve birkaç gün sonra yedi hırsız bir olup Hırsız Kasım’ı öldürüp, onun mallarına sahip çıkarlar ve kızlarını da terk edip şehirden ayrılırlar. 
Masalda Verilmek İstenen Mesaj: Masalda hırsızlığın ve yalan söylemenin kötü bir şey olduğu üzerinde durulmuş ancak mesaj tam olarak çocuklara iletilememiştir.

Masal Kahramanları ve Olumsuz İletiler: Masalın olay örgüsü Hırsız Kasım, kızları, damatları, kuyumcu ve kadı üzerine kurulmuştur. Masalın sonunda hırsızlık yapan ve yalan söyleyen Kasım öldürülürken, onu öldüren damatlar hiçbir ceza almamıştır. Bununla birlikte Kasım'a uygun görülen ölüm cezasının da çocukların eğitimi açısından sakıncalı olduğunu düşünüyoruz.

6. Momayniñ Ecri (Yaşlı Kadının Emeği) (Zaman-Şavdun 1982: 125-126)

Olay Örgüsü: Padişah ferman verir ve yüksekliği yüz kulaç, genişliği on kulaç, budaksız, dümdüz bir ağaç istediğini söyler. Padişahın askerleri böyle bir ağaç aramaya koyulur, uzun süre ararlar ve sonunda bulurlar. Bir ninenin evinde bulunan ve büyük zahmetle yetiştirdiği dut ağacını kesip nineye de birçok altın verirler. Nine bu duruma çok sevinir.

Masalda Verilmek İstenen Mesaj: Masalda verilen emeğin karşıllğının günün birinde mutlaka alınacağı düşüncesi işlenmiştir.

Masal Kahramanları ve Olumsuz İletiler: Masalda padişah, onun askerleri ve yaşlı nine üzerinden mesaj verilmiştir. Masalda yukarıda sözünü ettiğimiz düşünce kahramanlar üzerinden verilirken, çevre bilinci konusunda eğitimsel anlamda aynı duyarlılığın gösterildiğini söyleyemeyiz. Masalın sonunda yaşlı nine uzun emekler sonunda yetiştirdiği ağacın para karşılığında kesilmesine sevinmektedir. Bu davranışı, çocukların çevre bilinci kazanması açısından son derece sakıncalı buluyoruz.

7. Cahanni Bextlik Kezgenler (Dünyayı Mutlu Gezenler) (Zaman-Şavdun 1982: 273274)

Olay Örgüsü: Haşim savaştan geri dönerken ağzıyla rüzgâr yapan bir kişi sayesinde değirmenin susuz döndüğünü görür. Haşim değirmeni çeviren kahramanı da yanına alarak, bir şehre gider. Geldikleri şehre hükmeden padişahın kızı çok iyi koşar ve kendisini koşuda geçecek olan kişiyle evleneceğini söyler. Rüzgâr çıkaran adam kızı geçer ve padişah ona altın vermek ister. Haşim ve arkadaşı altını almak için öyle büyük bir çuval hazırlarlar ki padişah bunu bir türlü dolduramaz. Padişah öfkelenerek, altınları geri almak ister ancak rüzgâr çıkaran kahraman üfleyerek padişahın adamlarını mahveder ve Haşim ile arkadaşı altınları eşit şekilde bölüşüp ömür boyu mutlu yaşarlar.

Masalda Verilmek İstenen Mesaj: Eğitimsel açıdan masalı değerlendirdiğimizde çocukların bu metinden kazançları olmayacağını rahatlıkla söyleyebiliriz.

Masal Kahramanları ve Olumsuz İletiler: Masaldaki kahramanlar Haşim, Haşim'in arkadaşı, padişah ve padişahın kızıdır. Masalın başkahramanı olan Haşim ve arkadaşı açıkgözlülük yaparak padişahtan hak ettiklerinden daha fazla para koparmak istemişler ve masalın sonunda fiziksel bir güç kullanarak amaçlarına ulaşmışlardır. Bunun dışında ele aldığımız masalı okuyan veya dinleyen çocukların açgözlülük, kaba kuvvet gibi olumsuz davranışlar edinebileceklerini rahatlıkla söylemek mümkündür.

8. Musa Eleyhissalamniñ Sayahiti (Musa Aleyhisselam'ın Seyahati) (Yakup-Eli 1982: 303-305)

Olay Örgüsü: Musa Aleyhisselam'a sefere çıkması için vahiy gelir. Yolda giderken, göl boyunda duran yeşil kıyafetli Hızır ile karşılaşır ve yola birlikte devam ederler. Gece olunca bir zenginin evinde konaklamak isterler, ama zengin adam onları evine kabul etmez. Hızır giderken iki elini açıp: “On koyun yüz, yüz koyun bin, bin koyun on bin olsun, Allahu 
Ekber." deyip dua eder ve Musa Aleyhisselam'la birlikte yola devam ederler. Gide gide bir dul hatunun evine gelirler. Hızır kendilerini çok iyi ağırlayan hatuna ise "Bir keçini biz yedik. Kalan keçini de kurt yesin." diye dua ederek Musa Aleyhisselam'la birlikte evden ayrılır. Hızır yolda giderken beş çocuktan birini göle batırıp boğar ve Musa onun Hızır olduğundan şüphe duymaya başlar. Hızır da zengin adam ile hatuna ettiği duaların sebebini ve çocuğu niçin boğduğunu Musa'ya şu cümlelerle ifade eder: "Benim ilk olarak karşılaştığım cimri zengine: On koyun yüz, yüz koyun bin olsun... diye dua edişim, onun pek cimri olmasındandır. Onun koyunları, ahiret günü geldiğinde yılanlar ve çıyanlar tarafından mahvedilsin. Deminki kadının iki keçisi olup, birini bize verdi; birini de kurt yesin diye dua etim. Kadın iki keçisi ile beş vakit namazını iyi yerine getiremiyordu. İki keçisini yok ettim. O şimdi meşguliyeti olmadan, namazını kaza etmeden kılıyor. Onun gideceği yer cennettir. Bu çocuk büyüdüğü zaman beş kişiyi öldürecekti. Bu yüzden, onu küçükken öldürdüm." Yapılan açıklamalar Musa'ya doğru gelir ve Musa iki eli göğsünde Hızır'a selam verir. Hızır gözden kaybolur.

Masalda Verilmek İstenen Mesaj: Ele almış olduğumuz bu masalda çocuklara, Hızır ve Musa Aleyhisselâm üzerinden ön yargılı davranmanın doğru olmadığı anlatılmak istenmiştir.

Masal Kahramanları ve Olumsuz İletiler: Masaldaki kahramanlar Hızır, Musa Aleyhisselam, zengin adam ve dul kadındır. Masalda yukarıda sözünün ettiğimiz olumlu düşünce kısmen işlenmiş olsa da metnin bütününü değerlendirdiğimizde çocuklar açısından sakıncalı unsurların masalda yoğun olarak yer aldığını söyleyebiliriz. Beddua edilmesi, bir çocuğun öldürülmesi gibi davranışlar eğitici olmasını beklediğimiz masal metinlerinde kesinlikle bulunmaması gereken hususlardır. Dolayısıyla masalın eğitimsel açıdan zayıf olduğunu söylemek mümkündür.

9. Buğa Təpivəliş (Boyunluğun Bulunuşu) (Zaman-Şavdun 1982: 35-36)

Olay Örgüsü: Nöder isimli çocuk eşeğini ve at arabasını alıp pazara doğru yola çıkar ve yolda bir boyunluk bulur. Nöder, boyunluğun sahibi gelip boyunluğu tanıyıp almasın diye torbaya koyup üstüne oturur. Yolda Nöder'i gören dede ona eşeğinin boynunda boyunluk olmadığını söyler. Nöder yolda bulduğu boyunluğun kendi eşeğine ait olduğunu görünce sinir olur.

Masalda Verilmek İstenen Mesaj: Masalda herhangi bir olumlu mesaj bulunmamakla birlikte, söz konusu metnin eğitimsel açıdan da sakıncalı unsurlar barındırdığını söylemek mümkündür.

Masal Kahramanları ve Olumsuz İletiler: Çocuklar açısından uygun olmadığını düşündüğümüz masallardan biri de "Boyunluğun Bulunuşu"dur. Masalda, başkahraman Nöder üzerinden olumsuz davranışlar örneklenmiştir. Masal kahramanı Nöder, yolda giderken bulduğu (kendinin olmasına rağmen bilmiyor) bir boyunluğu sahibi görüp istemesin diye saklamış ve kendi boyunluğu olduğunu fark ettiğinde ise çok sinirlenmiştir.

10. Tadan Bilen Nadan (Kurnaz ile Cahil) (Letip-Yunus 1982: 259-261)

Olay Örgüsü: Biri kurnaz biri cahil iki kişi iş bulmak için başka şehre gitmek isterler. Başka şehre giderken çölleri geçmeleri gerektiğinden kurnaz adam cahile fazla erzak taşımayalım der ve cahilin erzakını yiyip bitirirler. Gece olup cahil acıkınca kurnazın erzakından yemek ister ancak cahilin erzakından yiyen kurnaz adam ona kendi erzakından vermez. Bunun üzerine cahil adam kurnaz adamdan ayrılır ve bir tepeye çıkar. Tepede dururken iki kurdun altın sohbeti yaptığını duyar ve altının yerini öğrenir. Kurtlar altınları 
koruyan tekeyi öldürmenin yolunu da söylerler. Padişahın kızının gözü körmüş ve onu iyileştirmenin tek yolu da bu tekenin kanını gözüne sürmekmiş. Cahil adam bunu başarır ve padişah, tedavi şeklini kurtlardan öğrenip kızını iyileştiren cahili yanına vezir yaparak; kızıyla evlendirir. Cahil adam vezir olduktan sonra ava çıkar ve kurnaz ile karşılaşır. Kurnaza başından geçenleri anlatır. Kurnaz da o tepeye gidip kurtları bekler, ama kurtlar gelmediği için kaçıp gitmek zorunda kalır.

Masalda Verilmek İstenen Mesaj: Masalda, iyi insanların her zaman kazançlı olacağ düşüncesi cahil adam üzerinden okuyucuya verilmiştir.

Masal Kahramanları ve Olumsuz İletiler: Cahil adam, kurnaz, padişah ve iki kurdun kahraman olarak yer aldığı masalda olumsuz olarak söyleyebileceğimiz iki husustan biri kurnaz adamın ceza almamasıdır. Cahil adamı saf bulduğu için kandıran kurnazın masalın sonunda ceza alması beklenirdi. Bununla birlikte tekenin öldürülmesi ve kanının göze sürülmesi de masal metinlerinde olmaması gereken olumsuz davranışlardır.

\section{SONUÇ VE ÖNERILER}

Masalların eğitimsel manada çok önemli bir işlevi üstlendiğini söyleyebiliriz. Masallar çocukların dil öğretiminde, bilişsel, sosyal, psikolojik ve ahlakî gelişiminde önemli bir rol oynamaktadır. İçinde barındırdığı motifler, formellerle ve sade-yalın diliyle çocuklara hoşça vakit geçirtirken aynı zamanda iyiyi, doğruyu öğreten, hayal gücünü geliştiren ve dört temel dil becerilerinden özellikle dinleme ve anlamanın gelişmesini sağlayan masalların tümünün bu özellikleri tam anlamıyla barındırdığını söylemek mümkün değildir.

Masallar kültürel unsurların aktarımında da önemli bir rol oynamaktadır. Söz konusu unsurlar masallardaki kahramanlar aracılığıyla çocuklara iletilmektedir. Halk masalları ait oldukları toplumların kültürel özelliklerini günümüze taşırken aynı zamanda bünyelerinde barındırdıkları korkunç ve acıklı durumlarla da çocuklara zarar verdikleri bilinmektedir.

Bu bağlamda Kıbrıs Türk halk masallarına baktığımızda en önde gelen kahramanlar arasında padişah, vezir, şehzade, aile üyeleri, peri, dev, cadı, kurt, at, halayık (Afrikalı kadın köle), çiftçi, çoban, Fatmacık, Dildane, Dürdane vd. sayılabilir. Uygur Türk halk masallarında ise daha çok kadı, padişah, cahil, Nöder, Hoşunbay, Sadirahun, kurnaz, teke, kurt, çoban gibi kahramanlara rastlanmıştır.

Kıbrıs Türk halk masalarının birçoğunda padişaha rastlanırken Uygur Türk halk masallarında padişahın yanında kadı́nın daha ön planda olduğu görülmüştür. Kadı́nın ön planda olması, bununla birlikte Hızır, Musa Aleyhisselam'ın da masallara konu olması, Uygur Türklerinin dini daha yoğun yaşamalarına bağlanabilir. Padişahın ise ortak olarak masallarda yer almasını, Uygurların Osmanlıyı tanımalarına, özellikle geçmişteki yönetim şekillerinin padişahlıkla benzeşmesine ve Farsçanın etkisine bağlamak mümkündür. Kıbrıs Türkleri Anadolu'dan geldikleri için padişahın kahraman olarak Kıbrıs Türk halk masallarında daha fazla bulunmasının gayet doğal olduğu düşünülebilir.

Yine hem Kıbrıs Türklerinde hem de Uygur Türklerinde kurt, çoban vb. ortak masal kahramanlarına rastlanılmaktadır. Çobanların masal kahramanı olarak edebî metinlerde yer almasının, hayvancılığın her iki toplumda da uzun süreden beri geçim kaynağı olmasıyla açıklanabileceği düşünülmektedir. Masallarda yoğun olarak rastlanılan bir diğer kahraman olan kurt da bilindiği gibi Türk mitolojisinin ortak değerlerinden bir tanesidir.

Kıbrıs Türk halk masalarında peri, dev, cadı vb. hayal ürünü kahramanlara çok fazla yer verilirken Uygur Türklerinde gerçek hayatta rastlayabileceğimiz kahramanlara (Hoşunbay, Nöder, Sadirahun, cahil, kurnaz, nine vs.) daha çok rastlanılmaktadır. Uygur 
Türk halk masallarının olay örgüsüne baktığımızda da gerçekte yaşanabilecek olayların masallar içerisinde çok daha fazla yer aldığını ve bu bağlamda Kıbrıs Türk halk masallarından daha fazla gerçeğe yaklaştığını söylemek mümkündür.

Eğitimsel açıdan bakıldığında Kıbrıs Türk halk masallarında çocuklar açısından sakıncalı bulabileceğimiz unsurları önem sırasına göre şu şekilde sıralamak mümkündür: Ölüm, şiddet, kıskançlık, açgözlülük, yalan söylemek, ahlaksızlık, dilencilik ve sözden dönmek vs. Ele aldığımız masallardan hareketle Uygur Türk halk masallarında rastladığımız olumsuz unsurlar ise rüşvet, açgözlülük, yalan söyleme, hırsızlık, afyon kullanımı, beddua, ölüm vs.dir. İncelenen masallarda yer alan olumsuz unsurlardan ve masalların olay örgülerinden hareketle Uygur Türk halk masallarının eğitimsel açıdan Kıbrıs Türk halk masallarına göre daha zayıf olduğu söylenebilir. Uygur Türk halk masallarına dikkatle bakıldığında masalların sonunda verilmesi gereken dersin genellikle eksik bırakıldığı görülmektedir.

Kıbrıs Türk halk masallarında ölüm ve şiddet gibi unsurların yoğun olarak kullanılması Kıbrıs Türklerinin yakın zamana kadar savaşlarla meşgul olmasına; Uygur Türk halk masallarında ise rüşvetin yoğun olarak yer alması Uygur Türk toplumunun uzun yıllar Çin yönetimi ve baskısı altında kalmasına bağlanabilir.

Masalların eğitimsel işlevi yerine getirmesinde masal başı ve sonu tekerlemelerinin de önemli bir yeri vardır. Kıbrıs Türk halk masallarında bu tür tekerlemelere çoğunlukla rastlanırken Uygur Türk halk masallarında bu tekerlemelere rastlanamamaktadır.

Sonuç olarak halk masallarının eğitimsel açıdan gerekliliği yadsınamaz bir gerçektir. Ancak bunu yaparken içerisinde yoğun olarak olumsuz unsurlar barındıran masallar eğitimin dışında tutulmalıdır. Bir kısım masallar ise olumsuz unsurlardan arındırılarak çocukların eğitiminde kullanılmalıdır. Ele alınan metinlerden hareketle Uygur Türk halk masallarının Kıbrıs Türk halk masallarına göre çocuk eğitimi açısından daha ince bir süzgeçten geçirilmesi gerektiği söylenebilir.

\section{SUMMARY}

First Turkish sovereignty began in Cyprus with the conquest of the Island by the Ottoman Empire in 1571. Starting from this date, a dense Turkish population coming from Anatolia was settled in the island. These people were sent to Cyprus from different regions of Anatolia, has brought many cultural elements including oral literary products, handicrafts, shadow games etc. along with their traditions and customs. The people who have been living in the island in the process from the past to the present day, have contributed to the Cypriot culture by processing the oral products and cultural elements, and making additions and deductions on these products and elements so that shaping them according to their geographical and cultural background.

The geographical area where Uyghur Turks had first lived is the area where the rivers of Orkhon, Selenga and Talas are located. It is known that they established a state in Otuken in 745. The Uyghurs who have settled in Asia throughout history have established important cultural and agricultural cities such as Kashgar, Turpan, Beshbaliq and Hotan in this region, and they have advanced in art and literature. Today, Uyghur people live in the Uyghur Autonomous Region of Xinjiang, which is under the dominance of People's Republic of China. Throughout history, the Uyghurs have created and developed many oral folklore products, such as legends, stories, epics (Oghuz Kagan epic in Uyghur) and tales. 
The most prominent feature of the tales in the Turkish geography just as in the world is to have an educational function. We observe that tales affect children's Turkish language skills particularly of listening, reading, writing (indirectly) and speaking, and undertake an influential role in the development of these skills. It is known that the child's listening skills improve, especially when the tale is told to him/her by his/her parents, and they can develop their reading skills by reading the tales at later ages. We can also say that the tale is an effective literary product to teach children of the social moral values, and make them to gain these moral behaviors. For example, the child is told through advice method that lying, theft, deceiving, and laziness are bad habits. However, the listening / reading of how a person who lies, steals, deceives or is lazy is punished in a tale, leaves a more intense and wishful influence in children's inner world. It can also be asserted that tale is the first and most effective tool for making the child learn his/her social roles. In particular, the roles of family members can be comprehended through tales. Also, various advice and lessons can also be communicated through tales; and tales can lead the children to adopt the virtues including goodness, honesty, courageousness, sharing, respect, animal and human love. Consisting of intense motifs, rhymes, supernatural beings, and imaginary elements, the tales can appeal children to listen/read the literary genre in question with interest, and also contribute to their imaginary development. Creativity and non-stereotyped and free thinking are the most important things that we need in our modern life. The first foundation of this is established in the extraordinary, fantastic and unlimited world of the tales. A fantasy fairy-tale element that can be bizarre and funny for an adult perhaps may open up new doors in the horizon of a child. But when we dive into the unlimited world of tales, we encounter with all these positive things as well as negative ones. A mother killed by her daughter, a baby removed from the grave, a girl killed by her jealous siblings, a child despised by a stepmother, burned/cooked children, tricked-deceased people, slaughtered animals, black magic etc., are the negative elements and behaviors that we may encounter in the tales. However, it will not be right for children to be deprived of the tales because of these negative elements. What is primarily to be done here is to determine these elements with the help of field experts. After reviewing the texts, the tales should be removed from the elements that could harm the children, and then these tales should be included in their education.

An oral culture and literary transfer which starts from the pre-school period has a great importance in the formation of a common Turkish culture. The comparative literary works of the Turkish world for the identification of the texts that will provide this transfer are also very important in this respect. A common spirit in the Turkish world, similar to one created in Europe by literary works such as Grimm, Andersen and Aesop tales as well as Kalevela, Nibelungenlied, Iliad and Odessa epics, can be generated only through oral literary works and cultural elements. In this sense, we think that this work on Uyghur and Cypriot Turkish folk tales is important. In this context, 10 Cypriot Turkish folk tales and 10 Uyghur Turkish folk tales have been reviewed, and the heroes and negative elements in these tales have been examined and compared. There are some negative elements in the tales of both of these communities. From the texts examined, we can say that Uyghur Turkish folk tales are weaker than the Turkish Cypriot folk tales in terms of education, and that the lessons to be given at the end of the tales are often left missing in the Uyghur Turkish folk tales.

SEFAD, 2017 (38): 307-324 


\section{KAYNAKÇA}

ALPTEKİN, Ali Berat (2005). Hayvan Masalları. Ankara: Akçağ Yay.

BİLKAN, Ali Fuat (2001). Masal Estetiği. İstanbul: Timaş Yay.

ERCİLASUN, Ahmet Bican (1997). Türk Dünyası Üzerine İncelemeler. Ankara: Akçağ Yay.

GÖKBULUT, Burak (2010). Kıbrıs Türk Masalları ile Uygur Türk Masalları Üzerinde Karşılaştırmalı Bir Araştırma (İnceleme-Metinler). Doktora Tezi. İzmir: Ege Üniversitesi.

KARATAY, Halit (2007). "Dil Edinimi ve Değer Öğretimi Sürecinde Masalın Önemi ve İşlevi". Gazi Üniversitesi Türk Ĕ̆itim Bilimleri Dergisi 5 (3): 463-475.

LETIP, Tursun-YUNUS, Hocahmet (1982). Uygur Helk Çöçekliri. C. 3. Urumçi: Şincan Helk Neşriyati.

ŞİMŞEK, Esma (2001). Yukarıçukurova Masallarında Motif ve Tip Araştırması C.1. Ankara: Kültür Bakanlığı Yay.

YAKUP, Mirkamil-ELİ, Hesen (1982). Uygur Helk Çöçekliri C. 6. Urumçi: Şincan Helk Neşriyati.

YAVUZ, Muhsine Helimoğlu (2002). Masallar ve Eğitimsel İşlevleri. Ankara: Kültür Bakanlığı Yay.

YORGANCIOĞLU, Oğuz (1998). Kıbrıs Türk Folklorundan Derlemeler-Masallar I. Mağusa.

YORGANCIOĞLU, Oğuz (2006). Kıbrıs Türk Folklorundan Derlemeler-Masallar II. Mağusa: Arif ve Canbulat Basımevi.

ZAMAN, Nurmuhemmet-ŞAVDUN, Turgan (1982). Uygur Helk Çöçekliri C. 5. Urumçi: Şincan Helk Neşriyati. 